\title{
JOSHUA 24: SOME LITERARY AND THEOLOGICAL REMARKS
}

Johan Wildenboer

\author{
Research Associate, Department of Old Testament Studies \\ University of Pretoria \\ P. O. Box 16573 \\ Pretoria North, 0116 \\ South Africa \\ E-mail: johan.wildenboer@gmail.com
}

(Received 02/04/2015; Accepted 07/07/2015)

\begin{abstract}
The aim of this article is to discuss the role and function of Joshua 24 in the current Pentateuch/Hexateuch/Enneateuch debate. Although Joshua 24 presents several textual issues, the emphasis of the article is to augment the role of Joshua 24 as an inclusive text, with the aim of uniting Judeans and Samaritans in the Persian era by emphasising loyalty to the Torah. The article highlights several shared traditions between Judeans and Samaritans in Joshua 24. This approach leads to the conclusion that Joshua 24 was probably written to replace Joshua 23, a Deuteronomistic text with an exclusive stance towards the other nations.
\end{abstract}

\section{INTRODUCTION}

This study forms part of an investigation into the MT and LXX versions of Joshua 24. In this present study, I will focus exclusively on the MT text of Joshua 24. I will start with the history of research, with the emphasis on the role of Joshua 24 in the broader framework of the canon. Thereafter, I will discuss recent trends in the study of Joshua 24, before offering a proposal regarding the role and function of the MT of Joshua 24.

\section{THE ROLE OF JOSHUA 24 IN THE CANON DEBATE}

Joshua 24 is widely recognised as one of the most complex and even controversial 
texts in the Old Testament. ${ }^{1}$ Apart from the literary tension in the text, ${ }^{2}$ the role of Joshua 24 in the context of a broader narrative has always been controversial. In the context of classical source criticism, the classical Pentateuchal sources were identified in the book of Joshua (Steuernagel 1923; Eissfeldt 1964; Schmidtt 1964). More specifically, Joshua 24 was assigned to the Elohist source (E).

Martin Noth's ground breaking study (Noth 1943) managed to change the perception of a Hexateuch stretching from Genesis to Joshua. Noth envisioned the concept of a Deuteronomistic History that encompasses Deuteronomy 1-3, Joshua, Judges, $1 \& 2$ Samuel and $1 \& 2$ Kings. Although this hypothesis puts Joshua 24 in a Deuteronomistic context, Noth was unsure about Joshua 24 and described it as "überlieferungsgeschichtlich selbständiges und isoliertes Stück" (Noth 1943:9). The hypothesis of the Deuteronomistic History influenced many scholars in their interpretation of Joshua 24. Smend, in sharp contrast to his mentor Noth, had no problem in assigning Chapter 24 to the Deuteronomistic History, while Perlitt (1969:240) described Joshua 24 as a pure Deuteronomistic text, with no preDeuteronomistic elements (against Noth). Fritz (1994) also interpreted Joshua 24 as

1 "Das Letzte kapitel des Josuabuches (24) is ein ausserordentlich vielbearbeiter text in der Bibelwissenschaft,der sogar mehrfach monographish behandelt und noch viel haüftiger in Artikeln und Buchbeiträgen besprochen werderen ist" (Schmid 2012:37-38).

2 Noth (1953); Fritz (1994) and Nentel (2000) note several cases of glosses in the text of Joshua 24. These include:

1) Verse 1: the four categories of leaders play no further part in the chapter. The leaders were probably added to link chapter 24 to the previous chapter. The LXX reads "Shilo", instead of "Shechem".

2) Verse 2: Nahor and Tehar are not mentioned in the rest of the chapter.

3) Verse 5: The reference to Moses and Aaron is absent in the LXX.

4) Verse 9: The reference to Bileam seems like a secondary addition to the text. It clashes with the beginning of the verse and disrupts the style of the verse.

5) Verse 12: The reference to the two kings is problematic. Apart from the fact that it appears too late in the chapter (the battles against the Amorites is mentioned in verse 8), the LXX reads "twelve kings".

6) Verse 17: the term "our fathers" is probably a gloss. The LXX also omits most of the verse.

7) Römer (2006:536-539) considers verse 19-21 as a later insertion, because it contradicts the concept of the covenant ceremony in Josh 24. Aurelius (2003:175) also provides literary evidence which supports this hypothesis.

8) Verse 22: The LXX omits "and they said "Witnesses"”. 
the Deuteronomistic Historian's version of the end of the Landnahme. Even as the concept of a Deuteronomistic History began to take a different direction from Noth's concept, scholars still continued to view Joshua 24 in the shadow of a Deuteronomistic History. Recently, Nentel (2000:66-96) has described Joshua 24 as a combination of a Deuteronomistic History and a later Deuteronomistic redaction (DtrS).

The slow demise of Noth's hypothesis ${ }^{3}$ created the opportunity for a return of the Hexateuch. Consequently, some scholars have described Joshua 24 as the final chapter of a narrative stretching from Exodus to Joshua 24 (Bieberstein 1995) or as a final chapter to a Jerusalem History (Zenger 2004). The parameters of the Hexateuch have also undergone some radical changes, and these changes have a direct consequence on the interpretation of Joshua 24. Köckert (1988), Carr (1996), Schmid (1999), Otto (1999:84-99) and Gertz (2000) have argued for a literary break between the books of Genesis and Exodus. According to this hypothesis, these two distinct literary complexes were joined by a later redactional layer. Schmid (1999) and Gertz (2000) tie this redactional layer to the Persian era. Carr (2013), on the contrary, describes this redactional layer as pre-Priestly. On the other hand, Blum (1997:181-212; 2006:89106; 2011:43-71) has remained loyal to the idea of interconnected Pentateuchal themes, which includes the theme of the Landnahme to form a quasi or "weak" Hexateuch. As a result of this paradigm change, more scholars view Joshua 24 as a late, post-Deuteronomistic, or even post-Priestly text ${ }^{4}$ (Van Seters 1984; O'Brien 1989; Blum 1990, 1997; Anbar 1992; Schmid 1999). Analogous to this new direction, is the hypothesis of a Pentateuch/Hexateuch redaction ${ }^{5}$ (Brettler \& Römer 2000:401-

3 The list of scholars who reject the concept of a Deuteronomistic History is growing rapidly. Würthwein (1994:1-11), Westermann (1994), and Knauf (2000:388-398) were some of the first who raised concerns regarding Noth's hypothesis. Many have since followed suite.

4 Perlitt (1969), Koopmans (1990:401-413), Noort (1998), Konkel (2008) and Frevel (2011) still approach Josh 24 as a proto-Deuteronomistic text. Popovich (2009:87-98) makes a detailed case for a post-Deuteronomistic dating of Josh 24. He carefully dismantles his mentor Ed Noort's arguments for a pre-Deuteronomistic dating of the text. In his conclusion, Popovich argues that once one approaches Josh 24 as Einheitlich, a postDeuteronomistic dating seems inevitable. Furthermore, no-one has convincingly linked Josh 24 to the pre-Deuteronomistic elements in the first half of the book of Joshua.

5 The term "Pentateuch redaction" is rather ambiguous. According to Levin (1993) it refers to the redactional layer that combines the Yahwist and Priestly Code. Witte (1998) and Gertz (2000) use the term to describe the merging of Priestly and non-Priestly material in 
419; Otto 2000; Achenbach 2005:122-154). According to this model, there were several Priestly groups in the Persian period that influenced the formation of the Pentateuch. One group wanted to emphasise a Hexateuch, with the emphasis on the land, while another group wanted to draw attention to the Torah in creating a Pentateuch. According to this model, the Pentateuch group won this argument, as today we have a Pentateuch ending with the death of Moses, while the book of Joshua is integrated with the Former Prophets in the Jewish canon.

The concept of the Hexateuch has come full circle. Today, the Hexateuch is not built on continuous sources, but on late redactional activity. Some scholars subscribe to the Hexateuch hypothesis, but they find no role for Joshua 24 in their reconstruction of a Hexateuch (Kratz 2000:129-130, 208-210, 215, 220-221; Knauf 2007:217-224, 2008:109-110; Nihan 2012:105-109).

The tendency to view Joshua 24 as a post-Deuteronomsitic or even a post-Priestly text has provided the impetus for an Enneateuch instead of a Pentateuch or Hexateuch (Schmid 1999:209-230; Aurelius 2003; Schmitt 2004:181-192; Becker 2006:131161). For these scholars, texts such as Deuteronomy 34 and Joshua 24 are not conclusions of a literary corpus. Schmid epitomises this theory when he describes Joshua 24 as a "hinge" between Genesis-Numbers and Joshua-2 Kings. According to Schmid this hinge creates a division between Israel's Heilsgeshichte and her Unheilsgeschichte. According to Schmid's model an original Enneateuch was truncated to eventually form a Hexateuch.

the Pentateuch. Schmid (2007:241) on the other hand uses the term to denote the "redactional texts which have to do with the formation of the Pentateuch-in canonical texts: the Torah-and that shows an awareness of a literary horizon that compromises the entire Pentateuch". In this study, I use the term "Pentateuch redaction" to refer to the redactor who, according to Römer, Brettler and Otto, brought together $\mathrm{P}$ and Deuteronomy. According to Otto's hypothesis, the Priestly redactor was responsible for severing the book of Joshua from the Hexateuch to form an eventual Pentateuch. According to these scholars, this Pentateuch redaction was in competition with a Hexateuch redactor. The evidence of this redactional activity can be seen in texts such as Deuteronomy 34 and Joshua 24. 


\section{JOSHUA 24 IN RECENT STUDIES}

From the above, it is clear that the history of research regarding Joshua 24 has come full circle. Today, we are where we started, with Joshua 24 as a conclusion to a Hexateuch, albeit a very different Hexateuch than Wellhausen and his followers envisioned. Today, the emphasis is on a Deuteronomistic or even post-Priestly Hexateuch, and Joshua 24 is the conclusion to this late Hexateuch. Of course, there are many hypotheses today under the umbrella of the Hexateuch. One of the most noteworthy is the so-called Hexateuch/Pentateuch hypothesis, promoted by Brettler, Römer, Otto and Achenbach. This hypothesis postulates a Persian Hexateuch, which was abandoned in favour of a Pentateuch ending with the death of Moses. Otto (2000:219) describes Joshua 24 as the end of the Hexateuch, with no links to the following books, but Römer still remains loyal to the concept of a Deuteronomistic History and correlates the Hexateuch in the Persian era with the death of the Deuteronomistic History (Römer 2006:182). Although Otto and Römer differ in their interpretations regarding the existence of a Deuteronomistic History, they agree with the idea that the book of Joshua was severed from the preceding books, and consequently the Hexateuch became a Pentateuch.

In order to understand the Pentateuch/Hexateuch redaction hypothesis, one has to start with Deuteronomy 34. Perlitt (1994:123-143) influenced the study of Deuteronomy 34 when he published a seminal essay in which he described Deuteronomy as devoid of any traces of the Priestly stratum (P). This view quickly became the dominant view, despite attempts to return to the original idea that $\mathrm{P}$ is to be found in Deuteronomy 34 (Blum 1990:227-228, 287; Frevel 2000; Weimar 2008:10-17, 26-90; Schmidt 2009). Römer and Brettler (2000:401-419) follow Perlitt and ascribes verses $1 *, 4,5,6$ and 11-12 to the Deuteronomistic History. These verses relate to the transition from Moses to Joshua and urge the reader to read Deuteronomy in conjunction with book of Joshua. Verses 7-9 represent an attempt to create a transition to Joshua 24. Verses $1 *$, 3, 4, 10-12 represent a Pentateuch redaction, which aims to disconnect Deuteronomy from Joshua. According to Römer and Brettler's hypothesis, the Hexateuch redaction was ultimately rejected in favour of the 
Pentateuch redaction. This signifies for Römer a battle between Priestly groups during the Persian era. One group wanted a Pentateuch, with an emphasis on the Torah, while another group wanted a Hexateuch, with emphasis on the land. Joshua 24, as well as the aforementioned passages in Deuteronomy 34, typifies an attempt to harmonise these groups. ${ }^{6}$

The depiction of Joshua 24 as an attempt to create a Hexateuch is based on Blum's (1997:194-206; 2006:97-103; 2011:69-71) observation that Joshua 24 is linked to the concept of a Hexateuch, in contrast to his Pentateuchal KP and KD compositions. Blum made this observation during his daring attempt to untangle the knots between Joshua and Judges. According to Blum (1997:201-202; 2006:96-97) Shechem is thoroughly linked to the Pentateuch in the following ways:

- Joshua 24:32, with its reference to Joseph's burial place, harks back to Genesis 33:19, where Jacob bought a piece of land from Shechem's father.

- The ritual of disposing of foreign gods links Joshua 24 to Genesis 35:1-7.

- The reference to the foreign gods beyond the Euphrates (Josh 24:2, 14) refers to the gods of Laban (Genesis 33:30, 32). According to Blum (2006:98) this is a midrash, created to link the gods of Laban to the gods which Rachel took into her home. By creating this link, this episode is brought into the context of Terah, father of Nahor, father of Beuel, father of Laban. Thus, the designation of the gods beyond the Euphrates is linked to Jacob.

- The reference to the bones of Joseph (Josh 24:32) also creates a connection between Genesis and Joshua 24. The bones of Joseph play an important role in Genesis 50:45 and Exodus 13:19. In fact, these references remain incomplete

6 Blum (1990:76-88, 227) ascribes Deuteronomy 34:7-9 to his KP (Priestly Composition), and verses 10-12 to the KD (Deuteronomistic Composition). According to Blum (1990:88), the verses 10-12 (KD) seems to function as a conclusion to the book of the Torah of Moses. Nevertheless, he also notes the connection to other KD texts (e.g., Deut 31:14, 15, 23) which connects to the following Joshua-story (1990:110-111). The KP and KD compositions serve to link the aforementioned compositions to the Deuteronomistic History (1990:227). Schmitt (2007:181-192) takes a different approach by noting in Deuteronomy 34 an attempt to connect not only to a Pentateuch or Hexateuch, but also to the Former Prophets. This conclusion is of course, in direct opposition to the findings of Brettler, Römer and Otto. 
without the conclusion in Joshua 24.

- Joseph and Joshua both lived for 110 years.

- The oak of Shechem (Josh 24:26) also ties the story of Jacob to Joshua 24.

The theory of a Hexateuch redaction is strengthened by the term "Torah of God" in Joshua 24:26. According to Römer (2010:97) and Römer \& Brettler (2000:415) it is used as a term for the nascent Hexateuch in Persian times. ${ }^{7}$ The Pentateuch/Hexateuch redaction puts the text in late Persian times. In fact, the term is found in one other text, namely Nehemiah 8:18. The expression "statues and ordinances" (חק ומשפט) provides a parallel with Ezra and creates an alternative to the giving of the law at Mount Sinai. Blum (2006:98-106) expands the notion of Joshua 24 and the תורת אלהים as a late concept and he augments this fact when he describes Genesis 50:26 as a redactional link between the books of Genesis and Exodus. Blum expands this argument when he identifies the same redactional link between Joshua and Judges 2:6-8. Because he dates the redactional link between Genesis and Exodus as post-Priestly, the same applies to the link between Joshua and Judges. Blum's study reaffirms his hypothesis that Joshua 24 is based on the established Pentateuch.

In conclusion, the recent trend in biblical scholarship to date Joshua 24 as postDeuteronomistic (or even post-Priestly) seems well established. ${ }^{8}$ This has led to even further conclusions, depicting Joshua 24 as part of a Hexateuch redaction, competing with a Pentateuch redaction in Deuteronomy 34. The role of Shechem is central to this hypothesis.

\section{THE MASORETIC VERSION OF JOSHUA 24: A REASSESSMENT}

Konrad Schmid places the MT reading of Shechem as the location of the covenant

7 Not everyone agrees with this assumption. According to van Seters (2003:947-955) the term denotes the preceding covenant with its statues and ordinances. Rofé (2000:462-474) goes further in describing the Torah of God in opposition to the later Torah given to Moses. Rofé puts this theory against the background of an Ephraimite History, stretching from Josh 24 to 1 Sam 12.

8 There are noticeable exceptions. Carr (2006:159-180; 2012:7-36) rejects the idea of a postPriestly link between the books of Genesis and Exodus. He therefore adheres to the concept of a proto (non-Priestly) Hexateuch, with its conclusion in Joshua 24. 
ceremony in the context of a struggle between the Judeans and the Samaritans. As far as Joshua 24 is concerned, he points to various Priestly $(\mathrm{P})$ vocabulary in this chapter (2012:41) and concludes that P must serve as terminus ante quem for Joshua 24 (2014:42). The critical stance towards Samaritans, as reflected in Nehemiah 13:28-30, where Samaritans are counted amongst those who serve foreign gods, is pitted against Joshua 24. Therefore, Joshua 24 is younger than P and older than Nehemiah 13. This corresponds with the recent tendency to date Joshua 24 as a late, postDeuteronomistic or post-Priestly text.

In the introduction to his argument regarding the role of Shechem in Joshua 24, Schmid notes that the northern kingdom does not play a role in the books of Chronicles. The history of Israel is centred in Judah and Jerusalem. Put differently: the role of the northern kingdom is ignored during exilic and post-exilic times. In Joshua 24:1 Joshua gathers the whole of Israel, which means that the northern and southern kingdoms are implied. The next verse alludes to the fact that their forefathers served foreign gods in Mesopotamia. Joshua gives the people a clear choice: they can choose to serve foreign gods, or they can serve Yahweh. ${ }^{9}$ The chapter functions as an invitation to serve Yahweh exclusively, and at the same time it offers an aetiology of loss, as Judges-2 Kings tells the story of the loss of land due to the serving of other gods. This notion is embodied in the negative role of Shechem in Judges 9, where Shechem becomes the place where the earthly king, and not Yahweh, is anointed. According to the viewpoint of Joshua 24, Samaria and Yehud epitomised two independent provinces. Put differently: in the narrative time, the whole of Israel, the northern and the southern tribes are being addressed. In the narration time, Yehud and Samaria are addressed. The author(s) or Joshua 24 does not differentiate between the northern and southern tribes. Consequently, the chapter exhibits a pan-Israelite outlook (Blum 2006:103). Schmid puts Joshua 24 in a prophetic context of hope for the restoration of the whole of Israel, as found in prophetic texts (Jer 30:8f.; 31:27f.; Ezek 34:23ff..; 37:15-28; Ob 1:18ff.; Is 11:11-16; Zech 9:9ff.; 10:6ff.). The reaction to this notion, as found in texts such as Nehemiah 13:28-30 and Genesis 35:1-5, as

9 This is one of the main arguments against a Deuteronomistic background of Joshua 24. In Deuteronomy Yahweh chooses Israel. The people have no choice in the matter. 
well as the later actions of John Hycranus, meant that this prophetic notion the restoration of the whole of Israel was short-lived.

Schmid's hypothesis is strengthened by the research of Nadav $\mathrm{Na}$ 'aman (2000:141-161). According to Na'aman the whole complex of Shechem-traditions (Jos 8:30-32), with the Ebal and Gerizim-traditions (Jos 8:33-35; Deut 11:26-30; 27:4-8) were penned by a later scribe (2000:155). He also mentions, in accordance with Schmid, that Genesis 35:2b, $4{ }^{10}$ was composed by the author of Genesis 34, with the obvious intent to undermine the story of Joshua $24 .{ }^{11}$ Gunkel (1901: 343) also describes Gen 35:1-8 as "lose zusammengehäuftes 'Geröll”' while Keel (1973:305306,331 ) also reiterates the late dating of Genesis 35. Schmid's hypothesis could be expanded by the following arguments:

- The Samaritans saw themselves as the descendants of the tribes of Ephraim and Manasseh. Joshua is depicted as an Ephraimite. Furthermore, Joshua 24 ends with a reference to the mountains of Ephraim.

- In terms of Priestly office, the Samaritans believed that their lineage goes back to Phineas, son of Eleazer, the son of Aaron (Hjelm 2000:20). Eleazer plays an important role in Joshua 24, to the point where he is presented as Joshua's successor. Nevertheless, the last reference in the MT of Joshua 24 is to Phineas, while his role in the LXX version is expanded even more. In the MT, Eleazer and Phineas are appraised in a positive light as part of the faithful generation of Joshua.

- The role of the Jacob narrative is evident in Joshua 24. The Samaritans considered Jacob to be their ancestor. In light of this fact, the reference to the Jacob/Joseph narrative is used to include the Samaritans in the covenant.

- Texts such as Genesis 28, Deuteronomy 11:26-30; 27:4-8; ${ }^{12}$ Joshua 8:30-35 and

10 The term for foreign gods אלהי הנבר (Josh 24:20) is also found in Genesis 35:2.

11 Noort (1997:161-180) also discusses the relationship between Deut 11:26-30; 27:11-13 and Josh 8:30-35. As to the various positions of Joshua 8:30-35 in the MT, 4Q Josh and LXX, he concludes that the text was moved to its position in the MT to specifically connect it with Shechem.

12 According to Na'aman's careful analysis of Deut 11:26-30 and Deut 27:4-8, these texts were not originally part of Deuteronomy, but were added at a later stage. 
Joshua 24 were constructed and used to legitimise the sanctuary of Shechem. According to Na'aman (2000:141-161) the description of the building of the altar at Shechem (Josh 8:30-32) and the ceremony that took place facing the mountains of Ebal and Gerizim (Josh 8:33-35), were constructed to illustrate how the commandments of Deuteronomy 11:26-30 and 27:4-8 were carried out. Joshua 24 was written to explain how the covenant was established. Na'aman proposes that these texts were written between the fall of the first temple and the rebuilding of the second temple under Ezra and Nehemiah. The legitimisation of the cultic site at Shechem with its links to Jacob caused some conflict, because it created a rival temple to Jerusalem.

- Genesis 34, 35:1-8, 2 Kings 17:24-41, and especially texts from Nehemiah, were written to discredit the sanctuary of Shechem, or to put it more bluntly, these texts were written to discredit Joshua $24 .{ }^{13}$ I would like to elaborate on the Nehemiah texts:

- Schmid's reference to Nehemiah 13:28-30 as a reaction to the inclusive stance of Joshua 24, could be amplified by other texts in the book of Nehemiah. Nehemiah 9 offers an overview of Israel's salvation history, very similar to Joshua 24. However, the Jacob tradition is notably absent in Nehemiah. The Samaritans considered Jacob to be their ancestor, and therefore the absence of the Jacob tradition in Nehemiah 9 might well indicate an anti-Samaritan stance.

- Nehemiah 8:18 is the only text in the Old Testament, apart from Joshua 24, which mentions the תורת אלהים. Blum (2006:99) rightly notes that the reference to the תורת אלהים (Jos 24:26) is ignored by modern commentators. Blum and Römer (2010:97), associates this term with an attempt to create a Hexateuch. I would like to elaborate on the various interpretations of the term, before offering an alternative explanation.

13 Zakovitch (1980:30-37) describes the role and function of Genesis 35:2b, 4 in these words: "That place which you regard as a legitimate temple of God (Josh 24:26) is nothing but an unclean place; what was buried under the terebinth was nothing but the idols which Jacob had removed from the place. It is not possible for a place in which alien worship was buried to be regarded as a sacred place." 


\section{Excursus: The Torah of God}

חק ומשפט as a reference to the (2003:952) interprets the term תורת אלהים described in verse 25 rather than to a Hexateuch He points to Joshua 8: where the term חק ומשפט described there. ${ }^{14}$

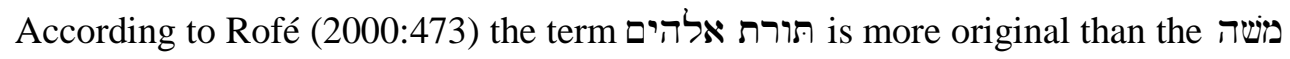
תורת. The covenant in Joshua 24 is a general covenant that could be administered by any religious leader. The Deuteronomistic תורת משה is still to come. Therefore, according to Rofé the תורת אלהים in Joshua 24 is in direct opposition to the משרה תורת He uses this argument to postulate the existence of an Ephraimite History, running from Joshua to 1 and 2 Samuel. This Ephraimite History is older and more original than the Deuteronomistic History. Rofé augments his argument with a reference to the Ephraimite characters evident in the books from Joshua to 1 Samuel. ${ }^{15}$

Blum (2006:99) points to linguistic uses of the term תורת אלהים and concludes that is used as a reference to the previous content of Joshua 24. Blum goes even further in showing that the term is used almost exclusively in Deuteronomic and Deuteronomistic literature. He uses the example of Deuteronomy 9:24 and 31 where the term can only refer to Deuteronomy or the whole Pentateuch. The only place where the term תורת is found outside Deuteronomistic literature is in Exodus 13:9. In most cases the term תורת is found in blessings and curses associated with a covenant ceremony. Blum further notes that the book of Joshua was not cut off from the preceding books to form a Pentateuch. Instead he argues that the Mosaic Torah was part of the DNA of Deuteronomistic literature (Blum 2011:69). Joshua 24 was written in order to create a "weak" quasi-Hexateuch. However, the authority of Moses meant משה משה that the Pentateuch ended in Deuteronomy 34 with Moses's death. The term

14 This is consistent with Van Seters's viewpoint that a Hexateuch never existed. According to his reconstruction of the literary canon, there is only a Deuteronomistic History (Deut-2 $\mathrm{Kgs}$ ) that was subsequently supplemented by the Jahwistic (Non-P) and Priestly (P) works which evolved into a Tetrateuch (Gen-Num).

15 Rofé builds his arguments on the assumption that the LXX version of Joshua 24 represents a more original link to the book of Judges. Rösel (1980:348-349) disagrees with this assumption and regards the MT ending of Joshua 24 as more original than the LXX. Blum (2006:101) interprets the hypothesis of a pre-Deuteronomistic link between the books of Joshua and Judges as too daring. 
תורת was not applicable to Joshua 24, because Joshua concluded the ceremony. Conversely, it could not be named תורת יהוושע, because that would undermine the authority of Moses. Therefore, the neutral term תורת אלהים was selected. The difference between Blum and Rofé, his erstwhile mentor, is significant. Blum interprets the term תורת אלהים as a natural evolution of the term תורת משה. Rofé however, interprets it as two opposing concepts. Blum revives the hypothesis of Wellhausen, and especially Noth, in stating that Deuteronomy 1-3 introduces a new literary work. This hypothesis is in sharp contrast to more recent studies on this subject. The fact is, however, that the term תורת משה which evolved out of the Deuteronomistic concept of תורה is evident in books that could be labelled Deuteronomistic (Josh 8:30-35; 23:6; 1 Kgs 2:3; 2 Kgs 14:6; 18:6;21:8-13; 23:25).

According to Römer and Brettler (2000:415) the תורת אלהים is a reference to the Hexateuch in Persian times. They point to the fact that the term is used in only one other text, namely Nehemiah 8:18. The תורת אלהים forms an integral part of their hypothesis of a Pentateuch redaction with emphasis on the Torah, and a competing Hexateuch redaction, with emphasis on the land.

\section{Conclusion}

I would like to propose that the term תורת אלהים (Josh 24:26) should be read as a reaction, or even correction of the תורת משהת. Furthermore, I would like to propose that the term תורת אלהים reflects an inclusive stance towards the Samaritan Pentateuch, and therefore it stands in opposition to the תורת משה.

I would like to expand this comment with a reference to Joshua 23, and especially the relationship between Joshua 23 and 24, the two separate conclusions to the book of Joshua. Today, we can observe a growing tendency to interpret Joshua 24 as a late, post-Deuteronomistic, or even as a post-Priestly text. ${ }^{16}$ Consequently, Joshua 23 is

16 Schmid (2012:21-49) notes the several Priestly concepts and words in Josh 24. This leads him to the conclusion that Josh 24 should at least be dated after P. Albertz (2007:199-217) also comments on the Priestly character of Josh 24 . He comes to the conclusion that Josh 24 originally belonged to a Hexateuch, but was consequently reworked through Priestly texts to align more closely with the Pentateuch. 
regarded as being older than Chapter $24 .{ }^{17}$ Römer (2010:91) follows Nelson (1997:268) in interpreting Joshua 23 as an end of the book of Joshua, while Joshua 24 constitutes the end of a larger literary work. However, it is worth noting that both chapters report a farewell address by Joshua. Furthermore, Joshua 23 (widely accepted as a Deuteronomistic text) uses the term ספר תורת משה (Josh 23:6), in opposition to Joshua 24's ספר תורת אלהים. Put differently: Joshua 24 seems to replace and correct the Deuteronomistic farewell speech of Joshua 23. The Deuteronomistic farewell speech connects to the book of Judges (Judges 2:6-10) with its emphasis on the remaining nations in the land, illustrating the destructive effect of the religious apostasy, to which the remaining nations (probably a veiled reference to the Samaritans) contributed. Joshua 24 interrupts this Deuteronomistic connection, and corrects the attitude towards the remaining people in the land.

Na'aman's comment regarding a later scribe who penned Deuteronomy 11:26-30; 27 and Joshua 8:30-35 seems appealing. However, it seems improbable that these texts were written by the same hand. Joshua 8:30-35 adheres to the commands of Deuteronomy 11:26-30 and 27. Furthermore, the reference to the Levites and ark in Joshua 8:30-35 also corresponds with the book of Deuteronomy. Most importantly, Joshua 8:30-35 implicitly uses the term תורת משה in contrast to the תורת אלהים of Joshua 24. The analysis of Deuteronomy 11:26-30; 27 and Joshua 8:30-35 in relation to Joshua 24 falls outside the parameters of this study, but certainly warrants a detailed investigation. ${ }^{18}$ I would like to emphasise that Joshua 24 seems to legitimise the cultic place of Shechem, while texts such as Genesis 34; 35:1-8; 2 Kings 17:24-41 and Nehemiah 8; 9 and 13:28-30 seems to refute this claim.

The cross connections between Joshua 24 and the book of Nehemiah has been noted earlier. In Nehemiah 8 the terms תורת משה אלהים and ised

17 Noteworthy exceptions to this thesis include Noth (1953:139); Smend (1970:130); Noort (1998:104,107); Görg (1991:102); Fritz (1994:229) and Knauf (2008:187-191). It is worth noting that the LXX version of Josh 8:30-35 (placed after Josh 9:1 in the LXX) associates the Torah of Moses in 9:2 (8:31 in the MT) with Deuteronomy.

18 Noort (1997:161-180) has done an illuminating study on the Theological, political and geographical elements of Joshua 8:30-35. He has come to the conclusion that Ebal and Gerizim was associated with Shechem from the start, but it was later relocated due to antiSamartian reasons. 
interchangeably. The reading of the law in Nehemiah 8 , together with the emphasis the and the role of the Levites, seem to correlate with the Deuteronomisticinspired texts of Joshua 8:30-35 and Deuteronomy 11:26-30 and 27:4-8. In referring to the days of Joshua, the term תורת אלהים is used. Nehemiah 8 seems to neutralise the proposed inclusive term תורת אלהים by using it with the Deuteronomistic term תתורת משה. In other words, Nehemiah 8 seems to react and correct the inclusive stance of Joshua 24.

\section{THE TEXT OF JOSHUA 24}

With the exception of Fritz (1994:233-252) and Nentel (2000:66-96), no contemporary scholars have approached Joshua 24 as a text with an intricate composition history. The text does exhibit some glosses, and possible insertions. I will briefly discuss the textual issues which have a direct influence of the hypothesis set out in this study.

Most commentators consider Joshua 24:1-28 and 24:29-33 to be separate literary entities. ${ }^{19}$ In the case of verses $29-33$, most scholars consider these verses to form part of a Priestly context, either a Priestly Fortscreibung (Blum 1997:210-211), Priestly redaction (Fritz 1994:251ff.) or Priestly addition (van Seters 2003:952). Nentel (2000:107-108), in contrast, considers verse 29-33 to be part of a late Deuteronomistic redaction. These considerations, as well as the complex relationship between Joshua 24:29-33 and Judges 2:6-10, falls outside the scope of this study, but it is worth noticing that the shared Judean/Samaritan traditions referred to in this study, is evident in verses 1-28 and 29-33.

Joshua's statement in verses 19-21 which amplifies the inability of the people to uphold the covenant seems to contradict the whole issue of the covenant. Therefore, Römer (2010:98) suggests that verses 19-21 should be viewed as a later insertion. Aurelius (2000:100) based this on textual grounds as he describes the people's pledge

19 Any attempt to disassociate verses 1-13 from 14-28 (Aurelius 2000:172-173; Kratz 2000:206-207; Becker 2006:139-161) raises more problems than it solves (Nihan 2012:264). 
in verse $21 \mathrm{~b}$ as a Wiederaufnahme of the pledge in verse 19b. According to Römer, verses 19-21 and 22b were inserted later when the concept of a Hexateuch was given up. This hypothesis is supported by the LXX, which omits the people's answer in verse 22b. Verse 19-21 serves to link to the book of Judges, where the consequences of the people's inability to serve Yahweh become reality (Römer 2010:98).

In the context of this study, verses 19-21 could be a later addition, added after the relationship between Judeans and Samaritans had worsened. This would further underline the notion that the concept of the whole of Israel before God was shortlived.

\section{FINAL CONCLUSIONS}

1) Through this study I have attempted to show that the cross-connected Hexateuch themes, especially the emphasis on the Jacob/Joseph story, the reference to the תורת אלהים, the emphasis on Shechem, and the reference to Eleazer, all point to a pro-Samaritan background for Joshua 24.

2) Israel's Heilsgeschichte is recounted in Joshua 24 in a Hexateuch-like manner, but with emphasis on the shared traditions between Judeans and Samaritans.

3) Joshua 24 seems to form part of a prophetic hope for the restoration of the whole of Israel. This restoration could only be achieved by renewed adherence to the Torah by Judeans and Samaritans.

4) Joshua 24 replaces the Deuteronomistic farewell speech of Joshua 23 by legitimising the sanctuary at Shechem and providing an alternative torah to the Torah of Moses.

\section{BIBLIOGRAPHY}

Achenbach, R 2005. Pentateuch, Hexateuch und Enneateuch. Eine Verhältnisbestimmung, ZAR 11:122-154.

Albertz, R 2007. Die kanonische Anpassung des Johuabuches. Ein Neubewertung seiner sog."Priesterschriftelike Texte", in Römer and Schmid 2007:199-217.

Aurelius, E 2003. Zukunft jenseits des Gerichts: Eine redaktionsgeschichltliche Studie zum 
Enneateuch. BZAW 319. Berlin: de Gruyter.

Barrick, W B \& Spencer, J R (eds) 1984. In the shelter of Elyon: essays on ancient Palestinian life in honour of GW Ahlström. JSOTSup 31. Sheffield: JSOT Press.

Becker U, 2006. Endredaktionelle Kontextvernetzungen des Josua-Buches, in Witte, Schmid, Prechel and Gertz 2006:139-161.

Bieberstein, K 1995. Josua-Jordan-Jericho. Archäologie, Geschichte und Theologie der Landnahmeerzählungen Josua 1-6. OBO. Friborg: Universitätsverlag, Göttingen: Vandenhoeck \& Ruprecht.

Blum, E 1990. Studien zur Komposition des Pentateuch. BZAW 189. Berlin/New York: de Gruyter.

1997. Die Kompositionelle Knoten am Übergang von Josua zu Richter: Ein

Entflechtungsvorschlag, in Lust and Vervenne 1997:181-212. 2006. The literary connection between the books of Genesis and Exodus and the end of the book of Joshua, in Dozeman and Schmid 2006:80-106.

2011. Pentateuch-Hexateuch-Enneateuch, in Dozeman , Römer and Schmid 2011:4371.

Carr, D M 1996. Reading the fractures of Genesis. Historical and literary approaches. Louisville: Westminster John Knox. 2006. What is required to identify pre-Priestly narrative connections between Genesis and Exodus? in Dozeman and Schmid 2006:159-180. 2012. The Moses story: literary and historical reflections, HeBAI 1-2:7-36.

Dozeman, T B \& Schmid, K (eds) 2006. Farewell to the Yahwist? The composition of the Pentateuch in recent European discussion. SBL Symposium Series 34. Atlanta: SBL.

Dozeman, T B, Römer, T C \& Schmid, K (eds) 2011. Pentateuch, Hexateuch, or Enneateuch. Identifying literary works in Genesis through Kings. SBL 8. Atlanta: SBL.

Du Pury, A, Römer, T C \& Macchi, J P (eds) 2000. Israel constructs its history. Deuteronomistic historiography in recent research. Sheffield: Sheffield Academic Press.

Edenburg, C \& Pakkala, J (eds) 2013. Is Samuel amongst the Deuteronomists? Current views on the place of Samuel in a Deuteronomistic History. Atlanta: SBL.

Eisffeldt, O 1964. Einleitung in das Alte Testament. Tübingen: Mohr.

Frevel, C 2000. Mit Blick auf das Land die Schöpfung erinnern. Zum Ende der Priestergrundschrift. HBS 23. Freiburg/New York: Herder. 2011. Die Wiederkehr der Hexateuchperspektive. Eine Herausforderung für die These vom Deuteronomistischen Geschictswerk, in Stipp 2011:13-53.

Frey, J, Schattner-Rieser, U \& Schmid, K (eds) 2012. Die Sameritaner und die Bibel: Historische und literarische Wechselwirkungen zwischen biblischen und Sameritanischen Traditionen. Studia Judaica/Studia Samaritana 7. Berlin/New York.

Fritz, V 1994. Das Buch Josua. Hat 1/7. Tübingen: Mohr Siebeck.

Garciá-Martinez, F (ed.) 1998. Perspectives in the study of the Old Testament and early Judaism: a symposium in honour of Adam S. van der Woude on the occasion of his $70^{\text {th }}$ Birthday. VTSup 73. Leiden: Brill.

Gertz, J C 2000. Tradition und Redaktion in der Exoduserzählung. Untersuchungen zur Endredaktion des Pentateuch. FRLANT 186. Göttingen: Vandenhoeck\& Ruprecht.

Görg, M 1991. Josua. NEB 26. Würzburg: Echter Verlag.

Gunkel, H 1910. Genesis. 3rd ed. GHK 1. Göttingen: Vandenhoeck \& Ruprecht.

Hjelm, I 2000. The Samaritans and early Judaism: a literary analysis. JSOTSup 303.

Sheffield: Sheffield Academic Press. 
Keel, O 1973. Das Vergaben der "Fremder" Götter in Genesis xxxv 4b, VT 23:305-336.

Knauf, E A 2000. Does Deuteronomsitic Historiography (DH) exist? in du Pury, Römer and Macchi 2000:388-398.

2007. Buchschlüsse im Josuabuch, in Römer and Schmid 2007:217-224. 2008. Josua. ZBKAT 6. Zurich: Theologisher Verlag.

Knoppers, G N \& McConville, J G (eds) 2000. Reconsidering Israel and Judah: recent studies on the Deuteronomistic History. SBTS 8. Winona Lake: Eisenbrauns.

Köckert, M 1988. Vätergott und Väterverheisssungen. Eine Auseinandersetzung mit Albrecht Alt und seine Erben. FRLANT 142. Göttingen: Vandenhoeck \& Ruprecht.

Konkel, M 2008. Sünde und Vergebung:Eine Rekontruktion der Redaktionsgeschichte der hinterein Sinaiperikope (Ex 32-34). Vor dem Hintergrund aktueller Pentateuchmodelle. FAT 88. Tübingen: Mohr.

Koopmans, W T 1990. Joshua 24 as poetic narrative. JSOTSup 93. Sheffield: JSOT Press.

Kratz, R G 2000. Die Komposition der erzählender Bücher des Alten Testaments: Grundwissen der Bibelkritik. UTB 215.Göttingen: Vandenhoeck \& Ruprecht.

Levin, C 1993. Der Jahwist. FRLANT 157.Göttingen: Vandenhoeck\& Ruprecht.

Lipschits, O, Knoppers, G N \& Albertz, R (eds) 2007. Judah and the Judeans in the fourth century B.C.E. Winona Lake: Eisenbrauns.

Lust, J \& Vervenne, M (eds) 1997. Deuteronomy and Deuteronomistic literature. BETL 133. Leuven: Peeters.

Mckenzie, S L \& Römer, T C (eds) 2000. Rethinking the foundations: historiography in the ancient world and the Bible. Essays in honour of John Van Seters. Berlin/New York: de Gruyter.

Nelson, R D 1997. Joshua: a commentary. Louisville: Westminster John Knox.

Nentel, J 2000. Trägerschaft und Intentionen des deuteronomistischen Geschichtswerks:

Untersuchungen zu Refelexionreden: Jos1; 23; 24; 1 Sam12 und 1 Kön 8. BZAW 297.

Berlin: de Gruyter.

Nihan, C 2012. The literary relationship between Deuteronomy and Joshua: a reassessment, in Schmid and Person 2012:79-114.

2013. 1 Sam 8 and 12 and the Deuteronomsitic edition of Samuel, in Edenburg and Pakkala 2013: 225-274.

Na`man, N 2000. The law of the altar in Deuteronomy and the cultic site near Shechem, in Mckenzie and Römer 2000:141-161.

Noll, K L and Schramm, B (eds) 2010. Raising a faithful exegete: essays in honour of Richard Nelson. Winona Lake: Eisenbrauns.

Noort, E 1997. The traditions of Ebal and Gerizim: theological positions in the book of Joshua, in Vervenne and Lust 1997:161-180.

1998. Zu Stand und Perspektiven: Der Glaube Israels zwischen Religionsgeschichte und Theologie, der Fall Josua 24, in Garciá-Martinez 1998:82-108.

Noth, M 1943. Überlieferungsgeschichtliche Studien. Tübingen: Niemeyer. 1953. Das Buch Josua. 2nd ed. HAT 7. Tübingen: Mohr Siebeck.

O’Brien, M A 1989. The Deuteronomistic History hypothesis: a reassessment. OBO 92.

Fribourg: Éditions. Universitaires/Göttingen: Vandenhoeck\& Ruprecht.

Otto, E 1999. Bruckensläge in der Pentateuchsforschung, TRU 64:84-99. 2000. Das Deuteronomium im Pentateuch und Hexateuch. Studien zur

Literaturgeschichte von Pentateuch und Hexateuch im Lichte des

Deuteronomiumrahmens. FAT 30. Tübingen: Mohr Siebeck.

Otto, E \& Achenbach, R (eds) 2004. Das Deuteronomium zwischen Pentateuch und 
Deuteronomistischem Geschictswerk. FRLANT 206. Göttingen: Vandenhoeck \& Ruprecht.

Perlitt, L 1968. Bundestheologie im Altes Testament. Neukirchen-Vluyn: Neukirchener Verlag. 1994. Priesterschrift in Deuteronomium34? VT 59:475-494.

Popovich, M 2009. Conquest of the land, loss of the land. Where does Joshua 24 belong?, in von Ruiten and de Vos 2009:87-98.

Rofé, A 2000. Ephraimite versus Deuteronomistic History, in Knoppers \& McConville 2000:462-474.

Römer, T C 2010. Book-endings in Joshua and the question of the so-called Deuteronomistic History, in Noll and Schramm 2010:85-99.

Römer, T C \& Brettler, M Z 2000. Deuteronomy 34 and the case for a Persian Hexateuch, JBL 119/3:401-419.

Römer, T C and Schmid, K (eds) 2007. Les dernières rédactions du Pentatueque, de l' Hexateuge, et de l'Henneatuege. BETL 203. Leuven: Peeters.

Rösel, H N 1980. Die Überleitungen vom Josua-ins Richterbuch, VT 30:342-350.

Schmid K, 1999. Erzväter und Exodus: Untersuchungen zur doppelten Begründing der Ursprünge Israels innerhalb der Geschichtsbücher des Alten Testaments. WMANT 81. Neukirchen-Vluyn: Neukirchener Verlag. 2007. The late Persian formation of the Torah: observations on Deuteronomy 34, in Lipschits, Knoppers \& Albertz 2007:236-245. 2012. Die Sameritaner und die Judaër. Die biblische Diskussion um ihr Verhältnis in Josua 24, in Frey, Schattner-Rieser \& Schmid 2012:21-49.

Schmid, K \& Person, R (eds) 2012. Deuteronomy in the Pentateuch, Hexateuch, and the Deuteronomistic History. Tübingen: Mohr Siebeck.

Schmidt, L 2009. P in Deuteronomium 34, VT 59:475-494.

Schmitt, G 1964. Der Landtag von Sichem. Stuttgart: Calwer Verlag.

Schmitt, H C 2004. DTN 34 als Verbindingstuck zwischen Tetrateuch und Dtr. Geschictswerk, in Otto and Achenbach 2004:181-192.

Smend, R 1970. Das Gesetz un die Völker, in Wolff 1970:494-504.

Sperling, S D 1987. Joshua 24 re-examined. HUCA 58:119-136.

Steuernage, 1 C 1923. Das Buch Josua. GHK 1,3 (2). Göttingen: Vandenhoeck \& Ruprecht.

Stipp, H J (ed.) 2011. Das deuteronomistische Geschichtswerk. ÖBS 39. Frankfurt am Main: Peter Lang.

Van Seters, J 1984. Joshua 24 and the problem of tradition in the Old Testament, in Barrick and Spencer 1984:139-158.

2003. Deuteronomy between Pentateuch and Deuteronomistic History, HTS 59/3:947-956.

Vervenne, M \& Lust, J (eds) 1997. Deuteronomy and Deuteronomistic literature. FS C.H.W Brekelmans. BETL 133. Leuven: Peeters.

Von Ruiten, J and de Vos, C (eds) 2009. The land of Israel in Bible, history and theology: studies in honour of Ed Noort. VTSup 124. Leiden: Brill.

Weimar, P 2008. Studien zur Priesterschrift. FAT 56. Tübingen: Mohr Siebeck.

Westermann, C 1994. Die Geschictsbücher des Alten Testaments: Gab es ein deuteronomsitisches Geschichtswerk? TB Altes Testament 87. Gütersloh: Gütersloher Verlag.

Witte, M 1998. Die biblische urgeschichte. Redaktions-und Theologiegeschichtliche Beobachtungen zu Genesis 1,1-11:26. BZAW 265. Berlin: de Gruyter.

Witte M, Schmid K, Prechel, D \& Gertz, J C (eds) 2006. Die deuteronomistischen 
Geschichtswerke: Redaktions- und religionsgeschichtliche Perspektiven zur "Deuteronomismus"-Diskussion in Tora und vorderen Propheten. BZAW 365. Berlin: de Gruyter.

Wolff, H W (ed.) 1970. Probleme biblischer Theologie: Gerard von Rad zum 70. Geburtstag. Munich: Kaiser Verlag.

Würthwein, E 1994a. Erwägungen zum sog. Deuteronomistischen Geschichtswerk: eine Skizze, in Würthwein 1994b:1-11.

Würthwein, E 1994b. Studien zum deuteronomistischen Geschichtswerk BZAW227. Berlin: de Gruyter,

Zakovitch, Y 1980. The object of the narrative of the burial of the foreign gods at Shechem, BeTM 25:300-337.

Zenger, E 2004. Einleitung in das Alte Testament. 5th ed. Stuttgart: Kohlhammer. 